present in pathological conditions, have characteristic movements on the paper chromatograms which are sufficiently specific to constitute a criterion for their recognition. Further, by means of this technique the existence of new compounds may be disclosed.
The writer wishes to thank Prof. H. P. Himsworth for his great interest and encouragement throughout, also Drs D. Hunter and J. H. Sheldon for providing rare pathological material, and Dr R. L. M. Synge for frequent and valuable advice on amino-acid problems. The technical assistance of Mr G. A. Rose is gratefully acknowledged.

\title{
REFERENCES
}

Albanese, A. A., Frankston, J. E. \& Irby, V. (1944). J. biol. Chem. 156, 293.

Albanese, A. A. \& Irby, V. (1944). J. biol. Chem. 153, 583.

Brand, E., Harris, M: M. \& Biloon, S. (1930). J. biol. Chem. 86, 315.

Consden, R., Gordon, A. H. \& Martin, A. J. P. (1944). Biochem. J. 38, 224.

Dent, C. E. $(1946 a)$. Lancet, ii, 637.

Dent, C. E. $(1946 b)$. Biochem. J. 40, xliv.

du Vigneaud, V., Kilmer, G. W., Rachele, J. R. \& Cohn, M. (1944). J. biol. Chem. 155; 645.

Fanconi, G. (1936). Jb. Kinderheilk. 147, 299.

Fishman, W. H. \& Artom, C. (1945). Proc. Soc. exp. Biol., N.Y., 60, 288.

Harrison, G. A. (1937). Chemical methods in clinical medicine, 2nd ed. London: Churchill.

Honda, M. (1922). J. Biochem., Tokyo, 2, 351.

Honda, M. (1923). Acta Sch. med. Univ. Kioto, 6, 405.

Hunter, D. (1946). In course of preparation.

Kirk, E. (1936). Acta med. scand., Suppl., 77, 1.

Lipmann, F. A. \& Levene, P. A. (1932). J. biol. Chem. 98, 109.

McCune, D. J., Mason, H. H. \& Clarke, H. T. (1943). Amer. J. Dis. Child. 65, 81.

McMeekin, T. L., Cohn, E. J. \& Weare, J. H. (1936). J. Amer. chem. Soc. 58, 2173.
Milkman, L. A. (1930). Amer. J. ${ }^{\star}$ Roentgenol. 24, 29.

Milkman, L. A. (1934). 'Amer. J. Roentgenol. 32, 622.

Mozingo, R., Wolf, D. E., Harris, S. A. \& Folkers, K. (1943). J. Amer. chem. Soc. 65, 1013.

Pauly, H. (1904). Hoppe-Seyl. Z. 42, 508.

Peters, J. P. \& Van Slyke, D. D. (1932). Quantitative clinical chemistry. London: Baillière, Tindall and Cox.

Pirie, N. W. (1932). Biochem. J. 26, 2041.

Posternak, J. \& Pollaczek, H. (1940). Arch. Sci. phys. nat. (v), 22, Suppl. pp. 234-235.

Rabinowitch, I. M. (1928). J. biol. Chem. 83, 333.

Sanger, F. (1945). Biochem. J. 39, 507.

Stadie, W. C. \& Van Slyke, D. D. (1920). Arch. intern. Med. 25, 693.

Stetten, de Witt (1941). J. biol. Chem. 140, 143.

Stowers, J. \& Dent, C. E. (1947). In course of preparation.

Toennies, G. \& Callan, J.'P. (1939). J. biol. Chem. 129, 481.

Toennies, G. \& Homiller, R. P. (1942). J. Amer. chem. Soc. 64, 3054.

Toennies, G. \& Kolb, J. J. (1939). J. biol. Chem. 128, 399.

Van Slyke, D. D. \& Kirk, E. (1933). J. biol. Chem. 102, 651.

Van Slyke, D. D., MacFadyen, D. A. \& Hamilton, P. B. (1943). J. biol. Chem. 150, 251.

Van Slyke, D. D. \& Palmer, W. W. (1920). J. biol. Chem. 41, 567.

Wada, S. (1930). Acta Sch. med. Univ. Kioto, 13, 187.

\section{Porphyrinuria in Rats Fed Oxidized-Gasein: a Preliminary Communication}

\author{
By C. E. DENT ANd C. RIMINGTON, University College Hospital Medical School, London, W.C. 1
}

(Received 15 October 1946)

The work described in this paper arose out of attempts by one of us (C.E.D.) to devise a diet sufficiently low in cystine and methionine to produce acute hepatic necrosis in rats (for review see Glynn, Himsworth \& Neuberger, 1945) with more success than was possible with natural proteins with a low content of these amino-acids.

Oxidized-casein (Toennies, 1942), produced by the action of hydrogen peroxide on casein dissolved in formic acid, appeared to be eminently suitable for this purpose since Bennett \& Toennies (1942) have shown that, when supplemented with tryptophan and methionine, it is nutritionally adequate for the young rat although growth is not quite as good as on natural casein. Food consumption was about $20 \%$ lower on the supplemented oxidized-casein diet than on the control diet. This would suggest that no essential amino-acids other than methionine and tryptophan are destroyed by the oxidation procedure. Comparative analyses (Toennies, 1942) of casein and oxidized-casein for threonine, serine, cystine, methionine and tryptophan show that from the latter protein, methionine and tryptophan are completely lacking, cystine is reduced from $0.36 \%$ to about $0 \cdot 16 \%$ whilst serine and threonine have not been affected. It was considered that methionine 
was oxidized to methionine sulphone which is known to be incapable of replacing methionine for growth purposes in the rat (Bennett, 1941).

Our experience with oxidized-casein confirms the claims of the American authors that by supplementation with tryptophan and methionine it can be made nearly as efficient as casein for growth purposes. Necrosis of the liver did not occur on the presumably cystine- and methionine-deficient diet containing oxidized-casein, but it was noticed that all experimental animals in this group began to pass a somewhat brownish urine in which two absorption bands could be distinguished. These were shown to be due to a porphyrin metal complex and a further study was therefore undertaken to ascertain what relation the porphyrinuria bore to the composition of the diet. Clearly porphyrinuria might have resulted from either a specific deficiency or from the presence of a toxic substance formed during the chemical oxidation of the protein.

The development of porphyrinuria without obvious signs of liver damage or the introduction into the diet of any of the recognized porphyrinurogenic poisons, e.g. lead, sulphonal, etc., is of interest. The identification of the responsible agent might bring to light a relation between pyrrol pigment metabolism and some well-known physiological substance.

In addition, oxidized-casein is now being suggested as a convenient methionine-free protein for biological experiments (Lyman, Moseley, Wood \& Hale, 1946) and a warning against its too ready acceptance as a harmless, simplified diet is timely.

\section{MATERIALS AND METHODS}

\section{Oxidized-casein}

Preparation. The method of Toennies (1942) was modified in several particulars. $800 \mathrm{~g}$. of casein (Grade A, British Drug Houses Ltd.) were added in small lots to 4.81. of 98-100\% formic acid in an enamelled pan provided with a wooden stirrer, the addition taking about $1 \mathrm{hr}$. The temperature was $17^{\circ}$ throughout. During the addition some lumps formed which mostly disappeared after $0.5 \mathrm{hr}$. of stirring. $800 \mathrm{ml}$. of $30 \%$ ('90-100 vol.') $\mathrm{H}_{2} \mathrm{O}_{2}$ were then added and the solution was stirred $1.5 \mathrm{hr}$., any remaining lumps being broken up as much as possible. $10 \mathrm{l}$. of water (distilled water used throughout) was then added followed by 5 l. of ice and water. Ammonia (sp.gr. 0.880) was added to bring the $\mathrm{pH}$ to about 4 (bromophenol blue greenish), about 41 . being needed. The temperature was kept below $30^{\circ}$ during the neutralization by, adding lumps of ice. Finally $5 \mathrm{l}$. more water were added and the precipitated protein was filtered off and pressed as dry as possible on large Buchner funnels. The cake was returned to the pan and stirred overnight with 201 . of water. Some lumps were seen at this stage. They were sieved off through gauze and separately worked up by the same method as the main batch. The main batch was again filtered. Filtration was much slower than before. After thorough washing with water on the filter the precipitate was stirred with $2.5 \mathrm{l}$. of acetone, filtered and dried in thin layers at $100^{\circ}$. The gritty crusts thus obtained were ground and spread out for some days before final storage. Yield $520 \mathrm{~g}$. About $30 \mathrm{~g}$. more were accidentally lost. Yield from lumpy material separately worked, $19 \mathrm{~g}$.

Comparative analyses of casein and oxidized-casein gave:

$\begin{array}{cc}\begin{array}{c}\text { Nitrogen } \\ \text { (g./100 g. protein) }\end{array} & \begin{array}{c}\text { Methionine } \\ \text { (g./100 g. protein) }\end{array} \\ 13.4 & 2.93 \\ 13.50 & 0.0 \\ 12.92 & 0.47\end{array}$

Original casein

Main batch of oxidized-casein Lumpy fraction of oxidized-casein

Nitrogen was determined by micro-Kjeldahl; methionine by the method of McCarthy \& Sullivan (1941). In view of the methionine analysis, the lumpy fraction was discarded. Two-dimensional chromatography (Consden, Gordon \& Martin, 1944) on a hydrolysate of the oxidized-casein was carried out side by side with a hydrolysate of the original casein. The oxidized-casein showed all the amino-acids present in the casein except methionine. Hydroxyproline, which always yields a weak spot, could not be distinguished but may have been present in small amount. Cystine did not appear on either chromatogram. Histidine appeared at first to be a little weaker, but this was not confirmed by comparison against casein hydrolysate using the more specific diazo reaction on the collidine one-dimensional chromatogram (Dent, 1947). Lysine may have been a little weaker. In addition, the oxidized-casein gave a strong spot with the characteristic colour and position due to methionine sulphone, and a weaker but quite definite one for cysteic acid which therefore accounts, in part at least, for the loss of cystine previously reported (for the positions of these spots see Dent, 1947). No methionine sulphoxide was seen. The spots for serine, threonine and tyrosine, whith might be expected to be partly oxidized by the $\mathrm{H}_{2} \mathrm{O}_{2}$, were quite as strong as in the untreated casein.

\section{Methionine sulphoxide and sulphone}

These were prepared by the methods of Toennies \& Kolb $(1939,1941)$. The purity of the preparations was confirmed chromatographically. "

\section{Rats}

Male rats of Wistar strain and of weight approximately $100 \mathrm{~g}$. were used, two on each diet (excepting No. 6 which was tested only on one rat). In the first experiment in which diets 1-4 were compared, litter-mates were employed as shown in Fig. 1. They were housed separately in 10 in. diameter glass funnels provided with a galvanized-iron wire grating; faeces and urine were separated by means of glass bulbs resting in the necks of measuring cylinders. The urines were collected every 2 days, a few drops of toluene being placed in the measuring cylinders at the beginning of each 2-day period. The food was supplied in the form of paste placed in receptacles suspended from the roof of the cage at such a height that the animals were forced to eat directly from them, so preventing the removal of food to the floor of the cage where crumbling occurs with inevitable contamination of the excreta. A similar arrangement has been used in extended nitrogen balance experiments and from the results obtained it is believed that an 
average of $95 \%$ of the total urinary output is collected. Body weights were recorded every 2 days. Water was provided ad lib. The diets were weighed out every day and mixed with water to a stiff paste before feeding. In this way they were invariably eaten without contaminating the excreta. Protein and amino-acid constituents of the various diets are shown in Table 1. Glutamic acid, although easily seen on the chromatogram of oxidized-casein, was added to diet 8 in view of the finding of Borek, Sheiniss, \& Waelsh (1946) that it antagonizes the growth-inhibitory action of methionine sulphoxide towards $L$. arabinosus. supplemented with methionine $(3,8,9$ and 10$)$. In some cases this difficult period was covered by a gradual transition, half casein and half oxidized-casein being fed for a few days.

The amino-acid supplements difficult to dissolve (tryptophan, cystine) were separately weighed, others were added every day to the food as an appropriate solution in the mixing water.

\section{Urine analysis}

Partition chromatograms. These were performed by the standard methods as applied to urine by Dent (1946).

\section{Table 1. Protein and amino-acid constituents of diets}

The amount of each supplement corresponds to that derivable from $0.95 \mathrm{~g}$. casein (Block \& Bolling, 1945).

\begin{tabular}{|c|c|c|c|c|c|c|c|c|c|c|c|c|}
\hline & Diets & $\begin{array}{l}\text { Casein } \\
\text { (g.) }\end{array}$ & $\begin{array}{l}\text { Oxidized- } \\
\text { casein } \\
\text { (g.) }\end{array}$ & $\begin{array}{l}l(-)- \\
\text { Trypto- } \\
\text { phan } \\
\text { (mg.) }\end{array}$ & $\begin{array}{c}d l- \\
\text { Methio- } \\
\text { nine } \\
\text { (mg.) }\end{array}$ & $\begin{array}{c}l(-)- \\
\text { Cystine } \\
\text { (mg.) }\end{array}$ & $\begin{array}{c}d l- \\
\text { Methio- } \\
\text { nine } \\
\text { sulphone } \\
\text { (mg.) }\end{array}$ & $\begin{array}{c}d l- \\
\text { Methio- } \\
\text { nine } \\
\text { sulph- } \\
\text { oxide } \\
\text { (mg.) }\end{array}$ & $\begin{array}{l}l(-)- \\
\text { Cysteic } \\
\text { acid } \\
(\mathbf{m g} .)\end{array}$ & $\begin{array}{l}l(+)- \\
\text { Glu- } \\
\text { tamic } \\
\text { acid } \\
\text { (mg.) }\end{array}$ & $\begin{array}{l}l(-) \text { - } \\
\text { Histi- } \\
\text { dine } \\
\text { (mg.) }\end{array}$ & $\begin{array}{c}l(+)- \\
\text { Lysine } \\
\text { hydro- } \\
\text { chloride } \\
\text { (mg.) }\end{array}$ \\
\hline & Casein & 0.95 & - & 16 & - & - & - & - & - & - & - & - \\
\hline 2. & Oxidized-casein & - & 0.94 & 32 & - & - & - & - & - & - & - & - \\
\hline 3. & $\begin{array}{l}\text { Oxidized-casein } \\
\text { + methionine }\end{array}$ & - & 0.92 & 32 & 27 & - & - & - & - & - & - & - \\
\hline 4. & $\begin{array}{l}\text { Oxidized-casein } \\
\text { + cystine }\end{array}$ & - & 0.92 & 32 & - & 22 & - & - & - & -- & - & - \\
\hline 5. & $\begin{array}{l}\text { Casein }+ \\
\text { methionine } \\
\text { sulphone }\end{array}$ & 0.95 & - & 16 & - & - & 33 & - & - & - & - & - \\
\hline & $\begin{array}{c}\text { Casein }+ \\
\text { methionine } \\
\text { sulphoxide }\end{array}$ & 0.95 & $\dot{-}$ & 16 & - & - & - & 30 & - & - & - & - \\
\hline & $\begin{array}{l}\text { Casein }+ \\
\text { cysteic acid }\end{array}$ & 0.95 & - & 16 & - & - & - & - & 4.5 & - & - & - \\
\hline 8. & $\begin{array}{l}\text { Oxidized-casein } \\
\text { + methionine } \\
\text { + glutamic acid }\end{array}$ & - & 0.95 & 32 & 27 & - & - & - & - & 180 & - & - \\
\hline 9. & $\begin{array}{l}\text { Oxidized-casein } \\
\text { + methionine } \\
\text { + histidine }\end{array}$ & - & 0.95 & 32 & 27 & - & - & - & - & - & 29 & - \\
\hline 10. & $\begin{array}{l}\text { Oxidized-casein } \\
\text { + methionine } \\
\text { +lysine }\end{array}$ & - & 0.95 & 32 & 27 & - & - & - & - & - & - & 68 \\
\hline
\end{tabular}

Carbohydrate and salts were given to the extent of $10.5 \mathrm{~g} . / \mathrm{rat} / \mathrm{day}$, of a mixture containing $71 \%$ corn starch, $24 \%$ sucrose and $5 \%$ salt mixture (Glaxo). In addition each rat received $0.5 \mathrm{ml}$. arachis oil, 2 drops cod-liver oil, $0.5 \mathrm{ml}$. yeast extract and $0.5 \mathrm{ml}$. of vitamin solution. The latter contained in $0.5 \mathrm{ml}$. : aneurin $20 \mu \mathrm{g}$, riboflavine $25 \mu \mathrm{g}$., pyridoxin $20 \mu \mathrm{g}$., calcium pantothenate $100 \mu \mathrm{g}$. and choline chloride $12 \mathrm{mg}$. Twice a week each rat was given 1 drop of vitamin $\mathbf{E}$ concentrate containing about $5 \mathrm{mg}$. of pure tocopherol.

The protein and carbohydrate were separately weighed every day. If any food was left from the previous day the amount was subtracted from the total of carbohydrate mixture to be fed that day. This achieved a relatively even intake of protein and supplements. Appetite was good on all the diets except 2 and 4 (Table 1 ) so complete eating of the diet was usual. Appetite was usually impaired for a few days on going over to the diets with oxidized-casein
A sample of $25 \mu \mathrm{l}$. of urine was taken for each test. 'In one case, acid hydrolysis was performed by sealing the urine $(25 \mu \mathrm{l}$.) in a capillary tube with $25 \mu \mathrm{l}$. of conc. $\mathrm{HCl}$ and immersing in boiling water for $24 \mathrm{hr}$. The contents were then evaporated to dryness to remove $\mathrm{HCl}$, dissolved in the minimum amount of water and transferred to the paper for chromatography.

Porphyrin determination. Porphyrin was observed to be present in the urines in the form of metal complex. This was no doubt due to unavoidable contamination of the specimens with zinc derived from the wire grid which supported the animals. For accurate quantitative determination of porphyrin content it was therefore necessary to liberate the free porphyrin by means of acid as follows. Urine $(5 \mathrm{ml}$.) was acidified with $0.5 \mathrm{ml}$. of $20 \%(\mathrm{w} / \mathrm{v}) \mathrm{HCl}$ and left for $0.5 \mathrm{hr}$. at room temperature. Sufficient saturated aqueous potassium acetate was then added to render the mixture neutral to congo red (about $0.5 \mathrm{ml}$. 
required) followed by $0.5 \mathrm{ml}$. of glacial acetic acid and $10 \mathrm{ml}$. of a mixture of 9 parts ether with 1 part light petroleum. The mixture was vigorously shaken, the lower layer discarded and the ether phase washed three times with an equal volume of water. The porphyrin was then transferred to $0.25 \%(w / v) ~ H C l$ by repeated shakings with about $1.5 \mathrm{ml}$. quantities, completeness of extraction being controlled by observation in ultra-violet light. The porphyrin content of the acid solution was then determined by fluorimetric comparison with a standard safranine solution (50 mg./1., calibrated against pure coproporphyrin 1) using a Pulfrich step-photometer and an Ilford filter No. 607.

\section{Tests for hepatic insufficiency}

Clinical. At the earliest stage of the onset of acute hepatic necrosis the rat becomes very inactive, loses its appetite and stands huddled in a corner of the cage. At this stage, palpation of the abdomen to determine the size of the liver is a most valuable procedure. Marked enlargement of the lobes of the liver is usually easy to detect and has been found only in acute hepatic necrosis. Other signs may also be present, e.g. hunched back, slow deep breathing, yellow staining around the penis, epileptiform convulsions. All these latter however can occur in the absence of acute hepatic necrosis and are therefore misleading. The rectal temperature falls rapidly as the hepatic necrosis develops, being often only about $24^{\circ}$ before death. Temperature has not, however, been of much help in diagnosing early liver failure.

Bile pigments in urine. Urobilin was tested for by direct spectroscopy after the addition of a trace of iodine. Bilirubin is detected best by Fouchet's test on $2 \mathrm{ml}$. of urine. It can readily be modified however for spot tests using only 10-25 $\mu \mathrm{l}$. of urine. The filter papers used for the test can be kept as permanent records. Generally speaking, bilirubin appears only about one day before death from hepatic necrosis. Rarely, when the disease has been very acute in its clinical onset, bilirubin may be absent throughout, even from the urine in the bladder at post-mortem. On two occasions the Fouchet test has been carried out during attacks followed by recovery. Bilirubin was excreted for about 5 days, this corresponding also to a period of weight loss and loss of appetite.

Amino-aciduria. Normal rat urines usually show a weak band with an $R f$ value of $0 \cdot 25-0.30$ which has been identified as glutamic acid. Glycine $(R f \quad 0.36)$ and alanine (Rf 0.57) appear weakly if at all. An excessive output of a wide range of amino-acids, showing easily on the chromatograms, when it occurs, is absolutely diagnostic of acute hepatic necrosis and provides valuable objective confirmation of the condition. It only appears late in the disease and has been absent in one out of about 20 cases, when the onset of the disease was exceptionally acute. One case has been followed during recovery. The excessive output of aminoacids disappeared gradually in about 3 days and closely followed the changes in bilirubin output. Bilirubin however may be present without excessive amino-aciduria, but not vice versa.

\section{Haemoglobin determination}

The Haldane method was used, the colour standard being calibrated so that $100 \%=13 \cdot 8 \mathrm{~g}$. $\mathrm{Hb} / 100 \mathrm{ml}$. Only occasional determinations were performed.

\section{Post-mortem examinations}

All animals were examined carefully when killed at the termination of experiments. Liver sections were taken in all cases, other organs being also examined if thought necessary. Negative findings are not reported here.

\section{RESULTS}

\section{Growth}

Fig. 1 shows the growth curves obtained from the rats on diets 1-4. This experiment can be taken as a biological test for the efficiency of the oxidative removal of methionine from the casein. It is seen

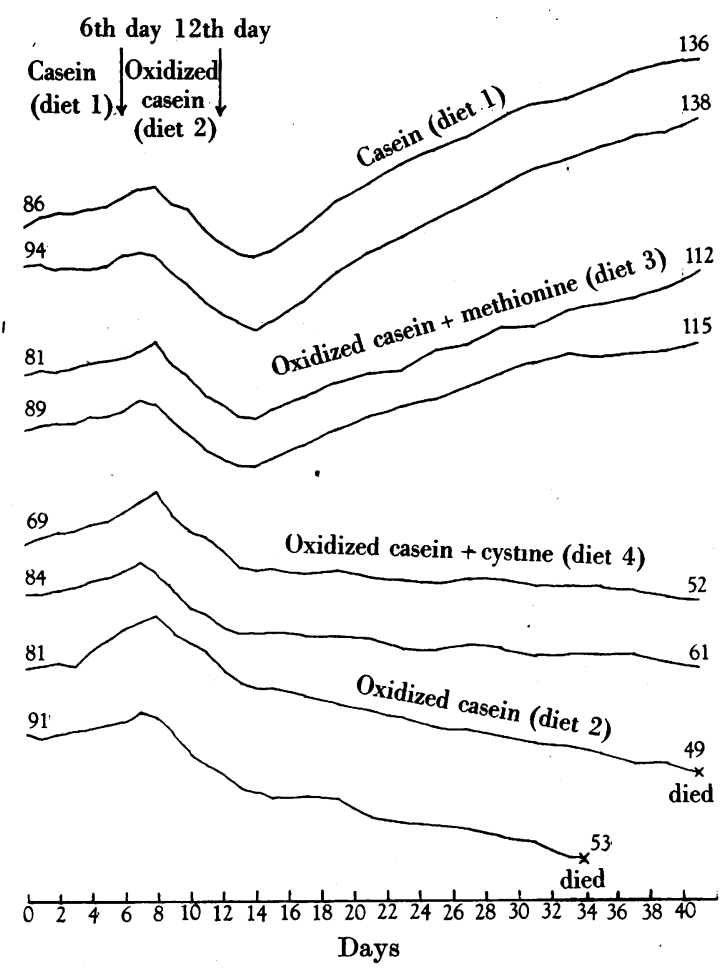

Fig. 1. Growth curves of individual rats on diets 1-4. All upper curves and similarly all lower curves are from litter mates. Body weights (g.) at beginning and end of the experiment are marked on the curves.

that no growth is obtained on the oxidized-casein supplemented only with tryptophan, in fact, weights steadily declined. Addition of methionine, on the other hand, in the quantity which would have been present in the casein, resulted in fair growth but not as good as in the control group on casein alone. These curves agree closely with those of Bennett \& Toennies (1942). The mean daily food consumption of each of our rats on the diet containing oxidizedcasein + methionine (diet 3) was $10.0 \mathrm{~g}$. as against $11.5 \mathrm{~g}$. for those on casein (diet 1). Addition of 
cystine in an amount containing the same total sulphur as the methionine supplement has only a slight effect in reducing the mortality. This confirms that methionine had been completely eliminated since, owing to the methionine-sparing action of cystine, had the elimination been incomplete, slight gains of weight could have been predicted when cystine was fed.

Growth curves are not presented for animals on diets 5-10 since 5, 6 and 7 followed closely diet 1, which also had casein as the source of protein, while 8,9 and 10 (containing oxidized-casein+ methionine) conformed to diet 3.

\section{Failure of oxidized-casein to produce acute hepatic necrosis}

Of two rats on oxidized-casein supplemented only with tryptophan (diet 2), one died of pneumonia on the 24th day. Its liver was histologically normal. The other died suddenly on the 42nd day. It was well at 10 a.m. but one hour later it was huddled in a corner of the cage, breathing slowly and jerkily just as does a case of acute hepatic necrosis. It then developed clonic spasms and died at noon. Its liver was not felt on abdominal palpation at any stage. There was complete absence of body fat; the liver and other organs were normal. Its serum specific gravity was 1.0163 (copper sulphate method of Phillips, Van Slyke, Dole, Emerson, Hamilton \& Archibald, 1945) which is equivalent to a plasma protein of $3.4 \%$ if the same factor (360) is used as for human blood.

The experiment was repeated with two 200 g. rats since Glynn, Himsworth \& Neuberger (1945) showed that with such large animals, acute hepatic necrosis may develop after only 8-22 days on a methionine and cystine deficient synthetic diet. During 50 days on diet 2, the animals lost 55-60 g. in weight but were otherwise normal except for increased por. phyrin excretion, the levels of which reached 15 times the normal (see Fig. 2).

One animal was then sacrificed and afforded the following post-mortem findings: Liver-few areas of early necrosis of irregular distribution, probably hydrotropic degeneration. Spleen-slightly deeper iron staining than usual. All other organs including bone marrow, normal. The bones did not fluoresce in ultra-violet light.

The companion to this rat was replaced on diet 1 whereupon he rapidly regained his lost body weight whilst porphyrin excretion promptly fell to near normal limits (see Fig. 2).

Four other rats (approx. 200 g.) were maintained in the same way on diet 2 for 20 days without producing acute hepatic necrosis.

Porphyrin excretion. The urinary porphyrin excretion of our experimental animals is represented by Figs. 2-6. It will be seen that whenever the diet contained oxidized-casein a prompt rise in porphyrin excretion occurred up to something like six times the normal level. No supplementation was able either to prevent or cure this porphyrinuria. When, however, cysteic acid, methionine sulphone or methionine sulphoxide was added to a casein-containing diet, in amount equivalent to the cystine or methionine content of the protein, no increase in porphyirin excretion occurred even after 18 days' administration.

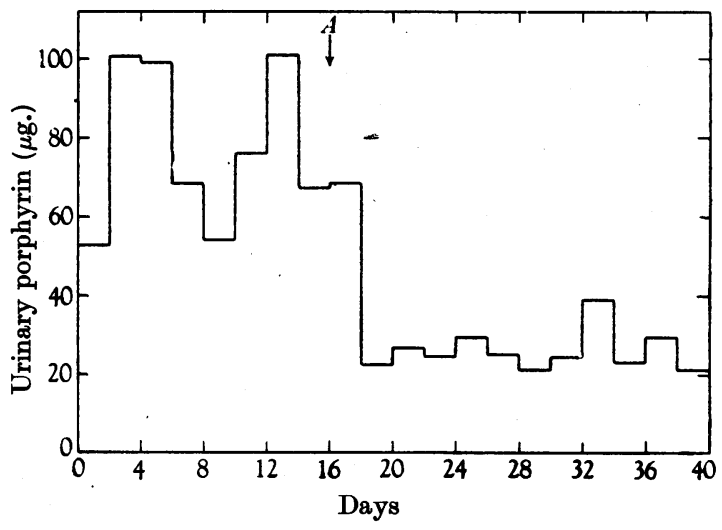

Fig. 2. Urinary porphyrin excretion (2-day collections) of rat on diet (no. 2) containing oxidized-casein. It had already been 5 weeks on this diet prior to commencement of porphyrin determinations. At $A$ placed again on basal casein diet (no. 1).

\section{Blood haemoglobin levels}

In six instances the level of haemoglobin in the blood was determined before and after the administration of oxidized-casein (diet 2) supplemented only by tryptophan for periods of 19-31 days but no significant change could be detected.

\section{Chromatography of urines on various diets}

Casein (no. 1). Normal chromatograms for rats' urines as described in the experimental section have invariably been found.

Oxidized-casein (no. 2). About 30 chromatograms were made at various times on the urines from the six rats on this diet. All were normal except the one rat which died, apparently from starvation. This rat showed slightly excessive amino-acid output during the last week of life. Analysis showed that this was chiefly due to an excess of one amino-acid only, which was identified as methionine sulphone by twodimensional chromatography. There were also complexes (? peptides) liberating large amounts of amino-acids, especially aspartic and glutamic acids, on $\mathrm{HCl}$ hydrolysis. Surprisingly, the urine withdrawn from the bladder at post-mortem contained practically no freo amino-acids; a hydrolysis was 


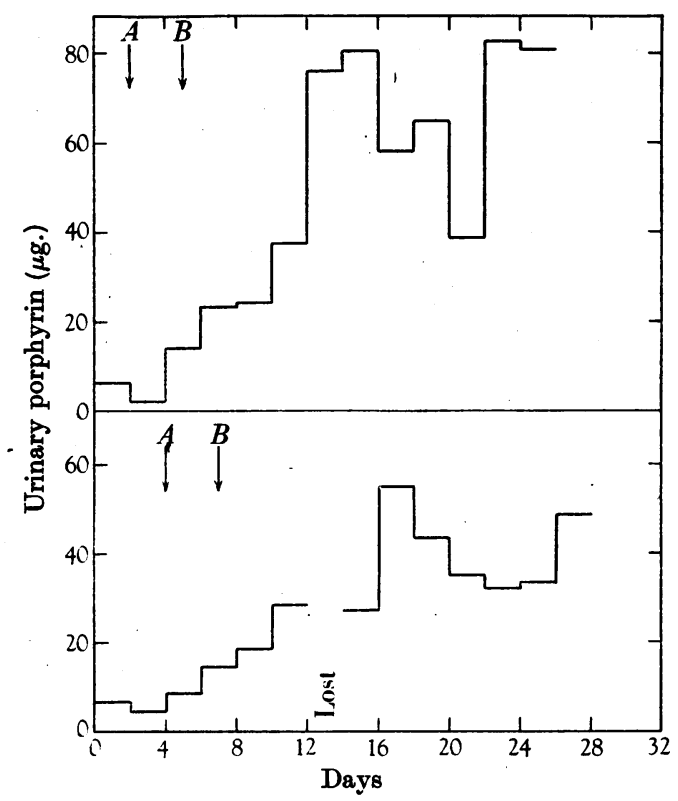

Fig. 3. Urinary porphyrin excretion (2-day collections) of two rats. At $A$ basal diet (no. 1) half-replaced by oxidizedcasein diet (no. 2). At $B$ complete replacement by no. 2.

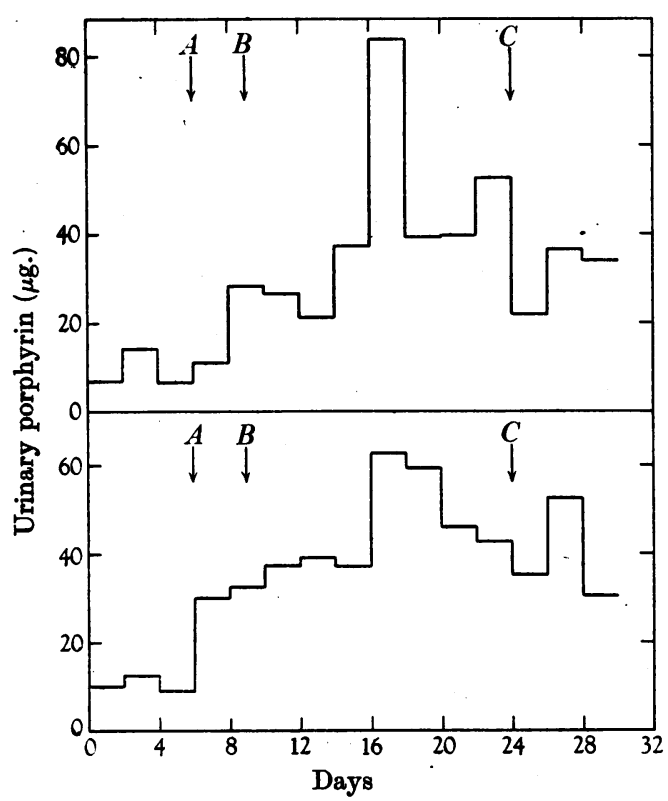

Fig. 4. Urinary porphyrin excretion (2-day collections) of two rats. At $A$ basal diet (no. 1) half-replaced by oxidizedcasein diet (no. 2). At $B$ complete replacement by no. 2. At $C$ methionine added (diet no. 3).

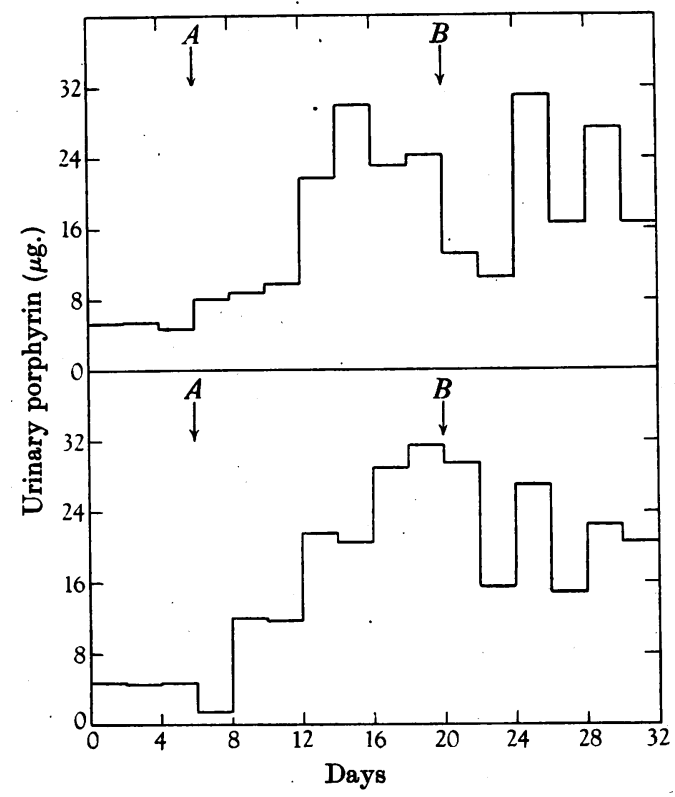

Fig. 5. Urinary porphyrin excretion (2-day collections) of two rats. At $A$ basal diet (no. 1) replaced by oxidizedcasein plus methionine (diet no. 3). At $B$ glutamic acid added (diet no. 8).

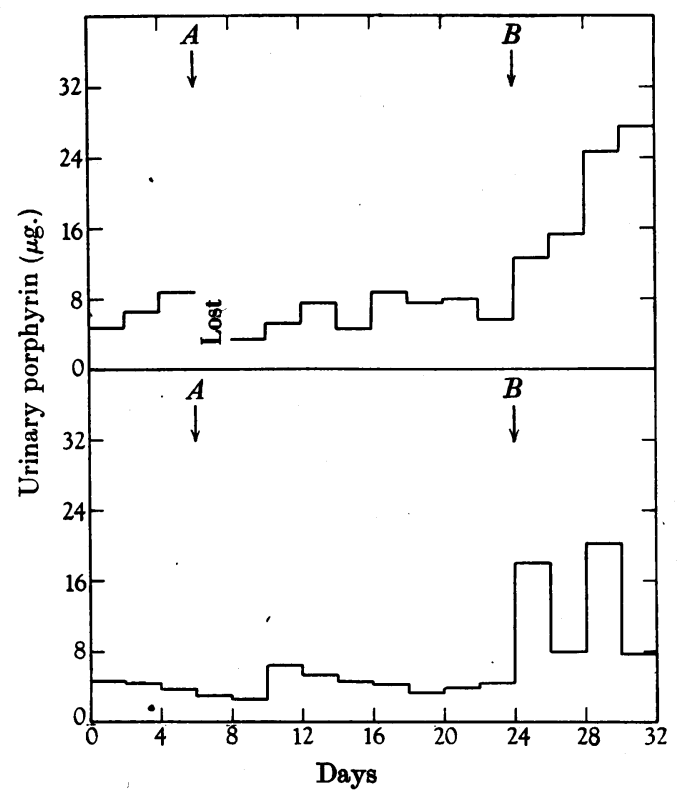

Fig. 6. Urinary porphyrin excretion (2-day collections) of two rats. At $A$ basal diet (no. 1) supplemented by methionine sulphone (diet no. 5). At $B$ replaced by oxidized-casein plus methionine plus histidine (diet no. 9). 
unfortunately not done on this specimen. Methionine sulphone could not be detected in the urine of any of the other five rats on the same diet.

Oxidized-casein plus methionine (no. 3). Normal chromatograms throughout.

Casein plus.methionine sulphone (no. 5). The urine always contained methionine sulphone which, roughly estimated by matching the intensity of the ninhydrin colour, accounted for at least half of the total amount added to the diet. Otherwise the urine was normal.

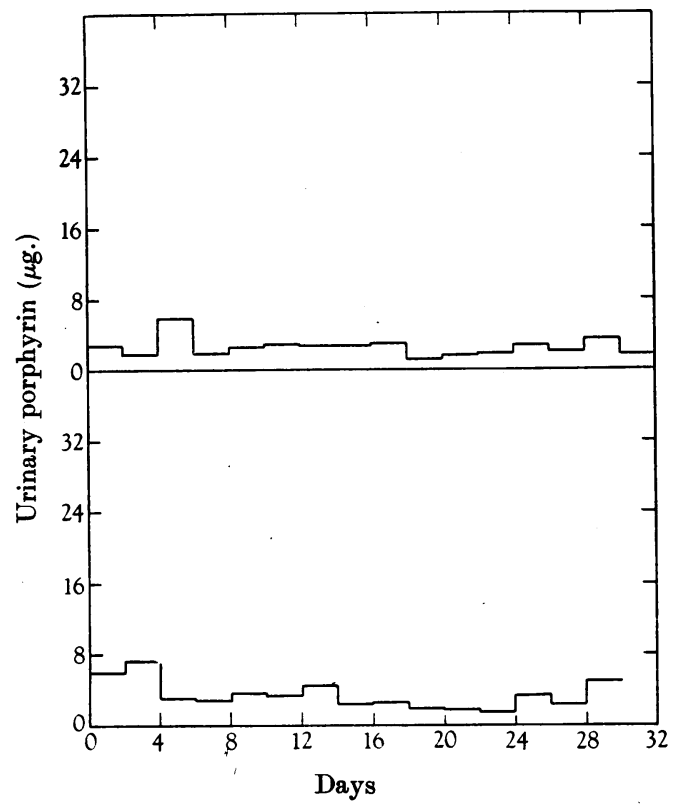

Fig. 7. Urinary porphyrin excretion (2-day collections) of two rats on basal diet (no. 1).

Casein plus methionine sulphoxide (no. 6). The urine invariably contained methionine sulphoxide. Rough matching showed that about one-fourth of the ingested sulphoxide was passing out unchanged into the urine. No other amino-acids were excreted in abnormal amount.

Casein plus cysteic acid (no. 7). Amino-acid output normal. No cysteic acid seen.

No regular chromatograms were performed on the urines from the rats on the other diets.

\section{DISCUSSION}

The experiments recorded have confirmed the fact that, in vitro, methionine in casein may be oxidized completely to the sulphone. The protein, apart from simultaneous loss of tryptophan, is not otherwise seriously affected as far as its growth-supporting properties go. This follows from the restoration of a growth rate nearly equal to that of the controls by supplementation of oxidized-casein with tryptophan and methionine.

The oxidized protein has, however, acquired another property, that of causing increased urinary porphyrin excretion, and in seeking to analyze this situation the following possibilities presented themselves: $(a)$ the oxidized-casein diet is deficient in some factor, possibly an amino-acid which has been destroyed by the oxidative procedure and the presence of which is essential for normal pigment metabolism; (b) oxidized-casein causes injury to the liver of such a nature that porphyrinuria results; (c) the oxidation procedure gives rise to a toxic substance, which is porphyrinurogenic.

Possibility $(a)$ and in part $(b)$ also were tested by feeding as supplement any or all of the amino-acids which analysis and our own chromatographic examination showed to be lacking or diminished in oxidized-casein as compared with the parent protein. Methionine deficiency was of course the first factor suspected since amino-acid diets lacking methionine and cystine have been shown to be not only incapable of supporting growth but also to be productive of acute hepatic necrosis which is massive in type. Porphyrinuria is an almost invariable feature of parenchymatous liver injury (Nesbitt \& Snell, 1942, etc.). The inability of methionine to prevent the increase of porphyrin excludes this type of liver injury as an explanation of the porphyrinurogenic action of oxidized-casein. Careful histological examination revealed, with one exception, no abnormalities in the livers of the rats on the diets of unsupplemented oxidized-casein and in this animal individual evidence of functional disturbance of the liver was not forthcoming from the other tests. All that can besaid is that if oxidized-casein produces a hepatic lesion, this is not detectable histologically.

$A$ priori support for possibility (c) was deduced from the structural similarity between methionine sulphone and sulphonal which is one of the best known of porphyrinurogenic drugs (Salkowsky, 1890-1). Methionine sulphone when fed failed, however, to raise the porphyrin excretion and the sulphoxide was similarly innocuous, as might have been expected from the fact that it can replace methionine in diets (Bennett \& Toennies, 1942). The oxidation product of cystine, cysteic acid, similarly failed to raise porphyrin excretion. The products to which tryptophan gives rise during the preparation of oxidized-casein are not known, so they could not be tested. One can only conclude that if a toxic substance is formed during the oxidative procedure, we have failled to identify it, although we would like to draw attention to the possibility that methionine sulphone in peptide linkage may have toxic properties which are not reproduced by feeding the free sulphone itself. 
That this latter possibility is not without experimental support is shown by the results of the urine chromatograms. On all the diets in which oxidizedcasein was fed, no methionine sulphone was found in the urine (except for one rat, already mentioned, which excreted it only during the last few days before death) although this was shown to be present in the acid hydrolysate of the protein. On the other hand, when methionine sulphone was fed as a supplement to a casein diet (no. 5) it largely overflowed into the urine unchanged. Hence it appears that the body must deal differently with methionine sulphone when, it is combined in the form of a peptide, and such a peptide may be the toxic porphyrinurogenic substance.

The failure of acute necrosis of the liver to develop on a diet devoid of methionine and containing very little cystine was unexpected. It is just possible that lesions would develop if the animals were kept on the diet for a longer time. The possibility cannot be excluded, however, that methionine sulphone may act as a protective substance.

Further studies will be undertaken of the phenomena described in this communication. The work has been interrupted at the present stage by the departure of one of us (C.E.D.) on a travelling Fellowship.

\section{SUMMARY}

1. It is confirmed that casein treated with hydrogen peroxide ('oxidized-casein'; Toennies, 1942) contains no methionine detectable analytically or by growth experiments.
2. Partition chromatography has revealed the presence in acid-hydrolyzed oxidized-casein of methionine sulphone and cysteic acid but of no other abnormal constituent reacting with ninhydrin.

3. Rats fed a diet including oxidized-casein rapidly develop prophyrinuria.

4. This porphyrinuria is not prevented by supplementation of the diet by methionine, tryptophan, histidine, lysine or glutamic acids alone or in various combinations, although satisfactory growth follows whenever methionine and tryptophan are both added.

5. Acute hepatic necrosis did not occur in rats fed oxidized-casein supplemented only with tryptophan. The livers of those receiving both methionine and tryptophan supplements were invariably normal.

6. The prophyrinuria observed whenever oxidizedcasein is present in the diet could not be associated with any histologically detectable liver damage.

7. Neither methionine sulphone nor cysteic acid when added to a casein diet induced porphyinuria.

8. Chromatographic examination of the urines indicates that methionine sulphone is differently metabolized when present in peptide linkage in oxidized-casein than when fed as a supplement.

9. A peptide containing methionine sulphone may be the porphyrinurogenic agent.

We wish to thank Messrs G. A. Rose and J. Evans for technical assistance rendered during the course of this investigation.

\section{REFERENCES}

Bennett, M. A. (1941). J. biol. Chem. 141, 573.

Bennett, M. A. \& Toennies, G. (1942). J. biol. Chem. 145 , 671.

Block, R. J. \& Bolling, D. (1945). The amino-acid composition of proteins and foods. Springfield: Thomas.

Borek, E., Scheiniss, P. \& Waelsch, H. (1946). Federat. Proc. 5, 123.

Consden, R., Gordon, A. H. \& Martin, A. J. P. (1944). Biochem. J. 88, 224.

Dent, C. E. (1946). Lancet, ii, 637.

Dent, C. E. (1947). Biochem. J. 41, 240.

Glynn, L. E., Himsworth, H. P. \& Neuberger, A. (1945). Brit. J. exp. Path. 26, 326.
Lyman, C. M., Moseley, O., Wood, S. \& Hale, F. (1946). Arch. Biochem. 10, 427.

McCarthy, T. E. \& Sullivan, M. X. (1941). J. biol. Chem. 128, 399.

Nesbitt, S. \& Snell, A. M. (1942). Arch. intern. Med. 69, 573.

Phillips, R. G., Van Slyke, D. D., Dole, V. P., Emerson, K., Hamilton, P. B. \& Archibald, R. M. (1945). Josiah Macy Jr. Foundation Rep., New York.

Salkowsky, E. (1890-1). Hoppe-Seyl. Z. 15, 286.

Toennies, G. (1942). J. biol. Chem. 145, 667.

Toennies, G. \& Kolb, J. J. (1939). J. biol. Chem. 128, 399.

Toennies, G. \& Kolb, J. J. (1941). J. biol. Chem. 140, 131. 